\title{
LEUCOCYTIC AND INFLAMMATORY EXUDATE IN THE UTERI OF PREGNANT AND PSEUDOPREGNANT RATS BEARING IUDS
}

\author{
T. RANDALL WRENN, JOAN R. WEYANT AND J. BITMAN* \\ Agricultural Research Service, United States Department of Agriculture, \\ Beltsville, Maryland 20705, U.S.A.
}

(Received 7th December 1970)

This experiment was planned to determine conditions favourable to the development of leucocytic invasion and exudate formation in uterine horns bearing intrauterine devices (IUDs). Three groups of rats were examined: (A) pregnant in one uterine horn and bearing an IUD in the contralateral horn, (B) pseudopregnant after mating to vasectomized males and bearing unilateral IUDs, and (C) pseudopregnant following mating to intact males and bearing bilateral IUDs.

Nylon double S-shaped IUDs were inserted into one or both horns of 125 adult Wistar rats using the transcervical approach described previously (Wrenn, Wood \& Bitman, 1968). Females were mated to intact or vasectomized males after IUDs had been in place for 1 month. The day on which a copulation plug was found was taken as Day 1 of pregnancy or pseudopregnancy. The animals were killed on Day 15 following mating. Each uterine horn having an IUD was flushed with $1.5 \mathrm{ml}$ of physiological saline into a Bauer-Schenck graduated centrifuge tube. The tubes were centrifuged and the packed-cell volume from each uterine horn measured to the nearest $0.004 \mathrm{ml}$. Smear preparations of the uterine contents were made and stained with Wright's stain. Results were compared statistically by Student's $t$ test.

The volume of packed cells obtained from horns containing IUDs contralateral to 15-day pregnant horns (Group A2, Table 1) was significantly greater $(P<0.001)$ than from IUD horns contralateral to 15 -day pseudopregnant horns (Group B2). Packed-cell volumes from the IUD horns of the pregnant group were also much greater $(P<0.001)$ than those obtained from flushings of pseudopregnant horns when both horns contained an IUD (Group C).

About $75 \%$ of the IUD horns of Group A contained visible leucocytic exudate. Stained preparations of these exudates from thirty-one IUD horns contralateral to 15-day pregnant horns showed the abundant presence of both small and large lymphocytes and polymorphonuclear leucocytes. In contrast to this, the IUD horns of pseudopregnant rats were so sparsely populated with cells that two-thirds could not be characterized by cell type. In only $34 \%$, a few lymphocytes and sporadic polymorphonuclear leucocytes were found. Rats with IUDs in both horns, and mated to normal males, showed no evidence of leucocytic

* Present address : Animal Science Research Division, ARS, Beltsville, Maryland 20705, U.S.A. 
infiltration in $71 \%$ of the horns. The remaining $29 \%$ showed very small numbers of cells.

The differences in the packed-cell volume of the luminal material flushed from uterine horns with IUDs clearly indicates that pregnancy in the opposite horn sustains the highest cellular content. Conditions which may favour the higher cell volumes include the presence of the embryos and their placentation, the introduction of spermatozoa 15 days previously, or the general hormonal status of the pregnant rat. The second alternative can be eliminated since the group of rats with bilaterally placed IUDs (Group C) which were also subject to spermatozoa but were pseudopregnant rather than pregnant, showed the lowest amount of cellular material.

TABLE 1

UTERINE HORN PACKED-CELL VOLUME AS AFFECTED BY IUDS ON DAY 15 OF PREGNANGY AND PSEUDOPREGNANGY

\begin{tabular}{|c|c|c|c|c|}
\hline \multirow[b]{2}{*}{ Group } & \multirow[b]{2}{*}{ Horn description } & \multicolumn{3}{|c|}{ Packed-cell valume } \\
\hline & & $\begin{array}{l}\text { No. of } \\
\text { uterine } \\
\text { homs }\end{array}$ & $\begin{array}{c}\text { Volume }(m l) \\
(M e a n \pm S . E .)\end{array}$ & $\begin{array}{c}\text { Statistical difference, } \\
\mathbf{P} \text { value }\end{array}$ \\
\hline A & $\begin{array}{l}\text { 1. Pregnant } \\
\text { 2. IUD }\end{array}$ & $\overline{33}$ & $0.052 \pm 0.009$ & $\begin{array}{l}A 2 \text { versus } B 2,<0.001 \\
A 2 \text { versus } G,<0.001\end{array}$ \\
\hline B & $\begin{array}{l}\text { 1. Pseudopregnant; } \\
\text { no IUD } \\
\text { 2. Pseudopregnant; } \\
\text { IUD }\end{array}$ & - & $0.007 \pm 0.001$ & \\
\hline $\mathbf{C}$ & $\begin{array}{l}\text { Pseudopregnant-both } \\
\text { IUD horns-mated to } \\
\text { normal males }\end{array}$ & 36 & $0.008 \pm 0.002$ & \\
\hline
\end{tabular}

A leucocytic invasion of the endometrium has been found to accompany IUDs in rats by a number of workers (Kar, Goswami, Kamboj \& Chowdhury, 1964; Greenwald, 1965; Delgado \& Salazar, 1966; Havránek, Dyková \& Tichý, 1967; Parr, Schaedler \& Hirsch, 1967; Marston \& Kelly, 1969; Parr, 1969). Parr concluded that some substance derived from leucocytes may exert toxic effects on ova and be responsible for IUD-induced infertility. Both bacterial infection and inflammatory reaction are probably more extreme in animals in which a silk suture is hung from a knot on the serosal surface of the uterine horn than under our conditions, using a monofilament nylon device wholly within the uterine lumen.

The differences we observed in uterine horn packed-cell volume in pseudopregnant and 15-day pregnant states may indicate that the pregnant rat is more susceptible to infection and/or inflammatory reaction. Ovarian hormones have been shown to influence leucocytic emigration and bactericidal activity in the uterus of the cow, rabbit and sheep (Rowson, Lamming \& Fry, 1953; Hawk, Simon, McNutt \& Casida, 1957; Brinsfield, Hawk \& Leffel, 1963;Hawk, Brinsfield, Turner, Whitmore \& Norcross, 1964) but an endocrine influence on 
the bactericidal activity of the rat uterus has not been described. Lamming \& Heap (1960) found that pseudopregnant rats and oestrogen-treated spayed rats did not differ in their ability to reduce the number of bacteria after experimental uterine infection. Our experience would indicate that some action of ovarian or placental hormones augments an inflammatory leucocytic response in uterine horns bearing IUDs. Kar et al. (1964) found fewer leucocytes in IUD horns of ovariectomized rats than in spayed rats given large amounts of oestrogen, while Stock, Ledger \& Campbell (1968) reported that there was less white-cell infiltration in endometrial stroma of nylon suture-containing oestrogen-treated rats than in suture-containing horns of oestrogen-deprived animals. No gross differences were described (Wrenn, Wood \& Bitman, 1969a) in the exudative material of IUD horns of spayed rats given small doses of oestradiol-17 $\beta$.

TABLE 2

LOCATION AND PERGENT REGOVERY OF IUDS FROM UTERINE HORNS CONTRALATERAL TO 16-DAY PREGNANT HORNS

\begin{tabular}{l|c|c|c|c|c|c}
\hline & \multicolumn{8}{|c}{\begin{tabular}{c} 
Recovery location \\
\cline { 2 - 7 }
\end{tabular}} & $\begin{array}{c}\text { Not } \\
\text { found }\end{array}$ & Cervix & $\begin{array}{c}\text { Lower } \\
\text { uterine third }\end{array}$ & $\begin{array}{c}\text { Middle } \\
\text { uterine third }\end{array}$ & $\begin{array}{c}\text { Upper } \\
\text { uterine third }\end{array}$ & Total \\
\hline $\begin{array}{l}\text { No. of IUDs } \\
\% \text { Recovery }\end{array}$ & $6^{*}$ & 1 & $18 \dagger$ & 12 & 3 & 40 \\
\hline
\end{tabular}

* These rats were bilaterally pregnant, and it is assumed that expulsion of the IUDs occurred before pregnancy.

$\dagger$ Includes one rat pregnant in the horn containing the IUD, the only unintended pregnancy of this group.

In rat uteri examined histologically on Day 4 of pregnancy, Marston \& Kelly (1969) constantly found leucocytic infiltration into the endometrial epithelium. The infiltration was usually extensive in the area of the IUD. In control horns, however, leucocytes could not be detected. During di-oestrus or on Day 4 of pregnancy, significant numbers of bacteria could not be cultured from horns contralateral to IUD horns, but could be cultured from the uterine flushings of the IUD horns even though they showed no obvious signs of infection. In a previous study, there had also been few signs of exudate described in IUD horns on Day 4 of pregnancy (Wrenn, Wood \& Bitman, 1969b).

The recovery of IUDs (Table 2) from rats which were fitted with a unilateral device and which subsequently became pregnant indicates an $85 \%$ retention of the IUD. The effectiveness of the IUD as a contraceptive in horns in which it was retained was $97 \%$. Only one rat had embryos in a horn containing an IUD.

Weyant, Wrenn \& Bitman (1970) have shown that IUDs need be in utero only 2 days in order to be effective, and Marston \& Chang (1965) have shown that removal of IUDs as late as Day 2 following mating will allow pregnancy to proceed in most rats. These observations are in accord with the possibility that mild inflammation and infection created by the IUD are the primary causes of the induced sterility. The present work supports this concept, and shows that 
the extent of leucocytic exudate accompanying the reaction changes with the endocrine status of the rat.

\section{REFERENCES}

Brinspield, T. H., Hawk, H. W. \& Lefrel, E. G. (1963) Control by ovarian hormones of the inflammatory response in the sheep uterus. 7. Reprod. Fert. 6, 79.

Delgado, R. \& Salazar, H. (1966) Histopathologic observations on the endometrium of rats bearing intrauterine contraceptive devices. Anat. Rec. 154, 458.

Greenwald, G. S. (1965) Interruption of pregnancy in the rat by a uterine suture. F. Reprod. Fert. 9, 9.

Havránek, F., Dyková, J. \& TichÝ, M. (1967) The effect of an intra-uterine suture on fertility in the rat. 7. Reprod. Fert. 14, 15.

Hawk, H. W., Brinsfield, T. H., Turner, G. D., Whitmore, G. W. \& Norcross, M. A. (1964) Effect of ovarian status on induced acute inflammatory responses in cattle uteri. Am. 7 . vet. Res. 25, 362.

Hawk, H. W., Simon, J., McNutr, S. H. \& Casida, L. E. (1957) Investigations on the endocrinecontrolled defense mechanism of estrous and pseudopregnant rabbit uteri. Am. F. vet. Res. $18,171$.

Kar, A. B., Goswami, A., Kamboj, V. P. \& Chowdhury, S. R. (1964) Effect of a foreign body on the response of the uterus of ovariectomized rats to estrogen. Steroids, 4, 159.

Lamming, G. E. \& Heap, R. B. (1960) Studies of the uterine environment of different species. II. The influence of ovarian hormones on experimental uterine infections. $\mathcal{F}$. Endocr. 20, xxiv.

Marston, J. H. \& Chang, M. C. (1965) Action of intra-uterine foreign bodies in the rat and rabbit. Proc. 2nd Int. Conf. Intra-Uterine Contraception, October 2-3, 1964. International Congress Series No. 86, pp. 243-247. Excerpta Med. Fdn, New York.

Marston, J. H. \& Kelly, W. A. (1969) The effect of uterine anastomosis on the action of an intrauterine device in the rat. 7 . Endocr. $43,95$.

PARR, E. L. (1969) Intrauterine foreign bodies: A toxic effect of leukocyte extracts on rat morulae in vitro. Biol. Reprod. $1,1$.

Parr, E. L., Schaedler, R. W. \& Hirsch, J. G. (1967) The relationship of polymorphonuclear leukocytes to infertility in uteri containing foreign bodies. 7. exp. Med. 126, 523.

Rowson, L. E. A., Lamming, G. E. \& FRY, R. M. (1953) Relationship between ovarian hormones and uterine infection. Vet. Rec. 65, 335.

Stock, L., Ledger, W. J. \& Campbell, C. (1968) Nylon suture in the rat uterus in the absence of estrogen. Arch. Path. 86, 171.

Weyant, J. R., WrenN, T. R. \& Brtman, J. (1970) Antifertility action of IUDs inserted in rats after mating. Contraception, 1, 209.

Wrenn, T. R., Wood, J. R. \& Brtman, J. (1968) A new technique for introducing IUDs into rat uteri. 7. Reprod. Fert. 16, 515.

WrenN, T. R., Wood, J. R. \& BITMAN, J. (1969a) IUDs and the biochemical responses of the uterus to estrogen in ovariectomized rats. Biol. Reprod. 1, 234.

WRENN, T. R., WoOD, J. R. \& BrTMAN, J. (1969b) Alterations in the uterine environment produced by IUDs. 7. Reprod. Fert. 19, 511. 